\title{
Pinter as Performer
}

Richard Hewett

School of Arts and Media, University of Salford, Salford, UK

Dr Richard Hewett

$\underline{\text { School of Arts and Media }}$

University of Salford

$\underline{\text { MediaCityUK }}$

Salford

$\underline{\mathrm{M} 502 \mathrm{HE}}$

r.j.hewett@salford.ac.uk 


\section{Pinter as Performer}

Harold Pinter worked successfully for many decades as an actor, making numerous, albeit intermittent, appearances on television, on stage and in film in addition to his distinguished writing career. Pinter's acting spanned the television eras I have identified as studio realism and location realism (Manchester: Manchester University Press, 2017). ${ }^{1}$ However, unlike many of his contemporaries, his screen performances do not represent a straightforward linear development from the scaled down, stage-derived codes of multi-camera studio to the less projected style of single camera film. In contrast, Pinter drew upon a variety of styles at each stage of his acting career. This article utilises five case studies to examine the extent to which he did not conform to the model of a stage actor adapting to screen work. The opening four texts are divided into two pairs; the first examines his work for multi-camera studio television, and the second for single camera film. The multi-camera case studies include a supporting role as Seeley in his own Armchair Theatre entry, A Night Out, alongside the BBC's 1987 adaptation of The Birthday Party, in which Pinter plays Nat Goldberg. The single camera pairing comprises Pinter's cameo as lawyer Saul Abrahams in the 1976 television movie Rogue Male, and his memorable appearance as the Director in David Mamet's 2000 short film Catastrophe. In addition to examining the range of techniques Pinter employed over his distinguished__yet comparatively little heralded__acting career, this article will also consider his 'performance' in his 2005 Nobel Prize in Literature lecture, 'Art, Truth \& Politics'.

Keywords: Harold Pinter; television acting; repertory theatre; screen performance; television history

\footnotetext{
${ }^{1}$ Richard Hewett, The Changing Spaces of Television Acting: From Studio Realism to Location Realism in BBC Television Drama (Manchester, 2017).
} 
Harold Pinter worked successfully for many decades as an actor, making numerous appearances on television, on stage and in film in addition to his distinguished writing career. Pinter's acting spanned the historical television eras I have identified elsewhere as studio realism and location realism. ${ }^{2}$ These saw a gradual evolution in television acting style from the scaled-down yet still somewhat stage-derived codes of multi-camera studio from the 1950 s to the 1980 s, to the less projected style of single camera location work more common in twenty-first century television drama. However, unlike many of his performing contemporaries, Pinter's screen appearances do not represent a straightforward linear development; instead, Pinter the actor draws upon a variety of styles at each stage of his career. His versatility_ possibly the result of his background as a writer and (less frequently) director _ meant that his acting style was tailored to the text first and to technological performing environs second. In light of this, it is perhaps surprising that his acting work has been so little focused on. While other areas of Pinter's artistic oeuvre such as his poetry and political activism receive attention in Basil Chiasson's The Late Harold Pinter (London: Palgrave Macmillan, 2017), little or no mention is made of his acting, even in Chiasson's opening consideration of Pinter's various 'stages and selves'. ${ }^{3}$ When Pinter himself briefly discusses acting in his interviews with Mel Gussow, published in 1994, he usually focuses upon his theatre work rather than his screen roles. ${ }^{4}$ Gussow's contribution to the 2001 Pinter at 70 collection is the only one to focus on his performing, yet it does not go much further than observing that Pinter is at his best playing authority figures with a hint of menace: 'which is why, of course, H. Pinter is such a natural to appear in works by H. Pinter' 5

\footnotetext{
${ }^{2}$ Hewett, The Changing Spaces of Television Acting.

${ }^{3}$ Basil Chiasson, The Late Harold Pinter: Political Dramatist, Poet and Activist (London, 2017), 2.

${ }^{4}$ Mel Gussow, Conversations with Pinter (London, 1994).

${ }^{5}$ Mel Gussow, 'Acting Pinter', in Pinter at 70: A Casebook, ed. Lois Gordon (New York and London, 2001), 262.
} 
After outlining Pinter's acting experience and training, this article will draw upon five case studies to examine his screen performances in order to demonstrate the extent to which he did not conform the typical model of a stage actor adapting to screen work. The first four texts are divided into two pairs. The first examines his work for multi-camera studio television, and the second considers his work for single camera location. The multi-camera case studies include an early supporting role as Seeley in his 1960 television play A Night Out, made for ITV's Armchair Theatre, alongside the BBC's 1987 adaptation of The Birthday Party for Theatre Night, in which Pinter plays Nat Goldberg. ${ }^{-}$The single camera pairing comprises two films made for television: Pinter's cameo as lawyer Saul Abrahams in Rogue Male (BBC, 1976) and his memorable appearance as the Director in David Mamet's 2000 adaptation of Samuel Beckett's one-act play Catastrophe, first broadcast on Channel 4 on 28 June 2001. In addition to examining the range of techniques Pinter employed over his distinguished yet comparatively little heralded acting career, the article will conclude with a consideration of Pinter's 'performance' in terms of his public persona, taking as its focus his 2005 Nobel Prize in Literature lecture ${ }_{2}$ 'Art, Truth \& Politics'.

\section{Acting Background}

Pinter first acted at Hackney Downs Grammar School, where he was selected by English teacher Joe Brearley to take the lead in Macbeth, winning plaudits from News Chronicle reviewer Alan Dent. ${ }^{7}$ However, his subsequent Romeo was damned with faint praise when reviewed in the school magazine, which found him lacking in the vocal abilities 'needed to bring out all the subtle cadences of the poetry' ${ }^{8}$ He then briefly attended the Royal Academy of Dramatic Art (RADA) in the autumn of 1948, and while he connected with a few fellow

\footnotetext{
${ }^{6}$ ITV's Armchair Theatre ran from 1956 to 1974 and BBC's Theatre Night from 1985 to 1990.

${ }^{7}$ Michael Billington, Harold Pinter (London, 2007), 13-14.

${ }^{8}$ William Baker, Harold Pinter (London and New York, 2008), 22.
} 
students, such as James Grout, Rachel Roberts, and Frances Hyland, Pinter generally detested RADA as being 'full of poofs and ponces, upstairs and downstairs, suspendered beauties, darlings and darlinged ... the instructors were mostly crap too'. ${ }^{9}$ It should be noted that the training provided by RADA at this time was largely focused on gesture and movement-based stage acting and voice projection, and had yet to embrace the Stanislavski-inspired naturalism being pursued on the opposite side of the Atlantic. $\frac{10}{}$ After faking (he claimed) a nervous breakdown, Pinter dropped out.

At this time Pinter began a letter-writing campaign to various radio producers at the $\underline{\mathrm{BBC}}$, offering his services for roles in dramas and features. Initial responses were not encouraging (correspondence held in the BBC's Written Archives Centre (WAC) sees Pinter $\underline{\text { addressed variously as 'A. Pinter', }{ }^{11} \text { 'Porter?', } 22 \text { 'Mr Puiter', }{ }^{13} \text { 'Miss Pinter' }{ }^{14} \text { and 'Herbert }}$ $\underline{\text { Pinta }^{15}}$ ), but Pinter was nothing if not tenacious. BBC producer R.D. Smith eventually gave him his first credited broadcast as narrator for the Home Service production Focus on Football Pools on 19 September 1950, followed by Focus on Libraries on 1 October. Pinter then took the role of Abergavenny in Smith's adaptation of Henry VIII (Third Programme, 14 January 1951), after which he wrote to Smith that 'my voice sounded almost unrecognizable. However, I feel I am beginning to understand what is needed in microphone technique, and working with you has been a most interesting and invaluable experience'. ${ }^{16}$ Pinter was invited to another audition shortly after Henry VIII and the ensuing report-for 'Herbert Pinta' -

\footnotetext{
${ }^{9}$ Billington, Harold Pinter, 20.

${ }^{10}$ Hewett, The Changing Spaces of Television Acting, 56-62.

${ }_{11}^{11}$ Letter from David Manderson, Drama Booking Manager, to 'A. Pinter', 17 July 1950, BBC Written Archives, Artists: Harold Pinter, file 1, 1950-62.

12 Letter to Donald McWhinnie, 13 July 1950, BBC Written Archives, Artists: Harold Pinter, file 1, 1950-62.

${ }^{13}$ Letter from Frank Hauser, Drama Department, to 'Mr Puiter', 17 July 1950, BBC Written Archives, Artists: Harold Pinter, file 1, 1950-62.

${ }^{14}$ Letter from John Arlott to 'Miss Pinter', 17 July 1950, BBC Written Archives, Artists: Harold Pinter, file 1, 1950-62.

15 'Audition Report: Herbert Pinta', no date, 1951, BBC Written Archives, Artists: Harold Pinter, file 1, 1950$\underline{62 .}$

${ }^{16}$ Letter to R. D. Smith, 24 January 1951, BBC WAC Artists: Harold Pinter, file 1, 1950-62.
} 
assessed his four audition pieces as follows: 'Not much attack', 'Produceable', 'Not

attractive', and 'Fair'. A note was added: 'RADA. Cockney. Good quiet approach'. ${ }^{17}$ Shirley Newnham, writing to Pinter on behalf of producer Douglas Cleverdon, explained that he was not, as a result of the audition, 'among those specially recommended for use in Feature programmes'. However, she went on, not discouragingly, 'This should not be taken to mean that there is any bar to your working in the future for producers either in Features Department or in any other department of the BBC ... failing to secure this recommendation does not reflect upon an artist's professional competence. ${ }^{18}$ In fact, later in 1951 Pinter went on to work on Denis Mitchell's North of England Home Service features Mr Punch Passes By and

\section{Dickens Goes to Yorkshire. ${ }^{19}$}

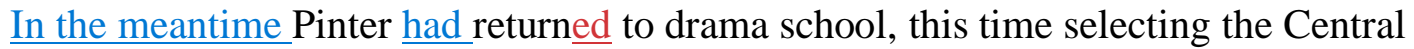
(now Royal Central) School of Speech and Drama, which he attended for two terms. Pinter found the teaching here more inspirational, particularly that of voice coach Cicely Berry, and he made a lifelong friend in fellow student Barry Foster. When considering Pinter's preference of Central over RADA it should be noted that, while the former was at this time equally stage-focused, it was arguably more welcoming of the new naturalistic style__at least in some quarters, as was seen in 1963 when several staff broke away to form the rival Drama Centre London. This trend towards a less stage-inflected performance style is reflected in Pinter's earliest television performances.

Pinter worked in repertory for the remainder of the 1950s, and his private correspondence with childhood friends and fellow 'Hackney gang' members Henry Woolf, Mick Goldstein and Jimmy Law reveals a gradual shift in attitude towards his occupation.

\footnotetext{
17 'Audition Report: Herbert Pinta', no date, 1951, BBC Written Archives, Artists: Harold Pinter, file 1, 1950 $\underline{62 .}$

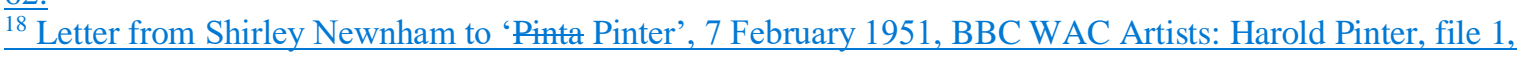
1950-62.

${ }^{19}$ Contracts for these parts in BBC WAC Artists: Harold Pinter, file 1, 1950-62.
} 
While touring Ireland with Anew McMaster's company in the early 1950s, Pinter is enthusiastic about his performing work, if a little facetious. In 1952, while playing Iago to McMaster's Othello, he writes to Woolf:

... I've been working hard at it, and may one day be remarkable in the part. At the moment I am brilliant in flashes, and quite consistent otherwise. Acting is all a matter of timing, of a coincidence between internal impulse and external execution. I might one day become a very good actor, though often I become disheartened. ${ }^{20}$

Pinter writes elsewhere that he is 'accounted a good actor' and that he 'has a flair for comedy' following his success as Hortensio in The Taming of the Shrew. ${ }^{21}$ Pinter also describes his Jack Worthing in The Importance of Being Earnest as 'somewhat brilliant', 22 and expresses admiration for Patrick Hamilton's Rope, stating that his performance as Brandon is 'the best work I've done in this business'. ${ }^{23}$ The seriousness with which he regarded acting at this time is indicated in a letter to Jimmy Law, written while Pinter was performing in J._B. Priestley's An Inspector Calls:

For me, as an actor ... it is of extreme interest. If only for the fact that it requires a more subtle, naturalistic approach than anything else in our repertoire. Yes, I knowIago is nothing if not subtle, but where Iago is stated, my part in this play is to such a degree suggested, understated__and even then I haven’t explained it properly ... With Iago, one has to project oneself into ... a creation of more complete, more utter (!) stature than oneself _ in this play one has to ... confine particles of one's

\footnotetext{
${ }^{20}$ Letter to Henry Woolf from Thurles, Ireland, no date, 1952, British Library Add MS 89094/2/3.

${ }^{21}$ Letter to Henry Woolf from Tipperary, Ireland, no date, 1952, British Library Add MS 89094/2/2.

${ }_{22}$ Letter to Michael Goldstein from the Theatre Royal, Waterford, 28 October 1953, British Library Add MS 89083/1/1/1/10.

${ }^{23}$ Letter to Michael Goldstein from County Carlow, Ireland, no date, 1953, British Library Add MS 89083/1/1/1/11.
} 
experience into the character, to express and catch its naturalness and commonness

... I know one projects one's life into any part, to give it stuff, to make it

understandable, but in this modern drama it's a more definite process. ${ }^{24}$

Such remarks indicate a Stanislavskian approach to his craft that was not yet de rigueur at British drama schools, ${ }^{25}$ but by the time Pinter moves to Colchester Rep in 1955 he is more likely to enthuse about cricket, and describes acting primarily as a means to an end: 'earning a living, earning a living'. ${ }^{26}$ By 1956 there is a sense that Pinter now regards performing as getting in the way of work on his book, The Dwarfs: 'I'm atrophied for the time being mainly through increasing pressure of the other work ... I have hours of learning to do today. As I get older it becomes less easy to compartmentalise'. ${ }^{27}$ By 1957, Pinter's tone has become extremely negative:

I'm utterly fucked to the teeth with regard to this acting racket. Nine out of ten plays are crap. The managements are crap. And the audiences are the worst crap of all. Still, at the moment, there's no way out. Some must work and some must play. ${ }^{28}$

Pinter's 'way out' of acting would arrive with the success of The Caretaker in 1960, after which writing became his chief source of income. However, it should be noted that his comments in fact relate to the pressures of repertory theatre performance, which required a rapid turnaround in terms of learning plays on a weekly basis, rather than a genuine disillusionment with acting itself. His earlier correspondence suggests a sincere interest in

\footnotetext{
${ }^{24}$ Letter to Jimmy Law from County Cork, Ireland, no date, British Library Add MS 89182/1/12. Emphasis in the original.

${ }^{25}$ Hewett, The Changing Spaces of Television Acting, 56-62.

${ }^{26}$ Letter to Jimmy Law from Colchester, no date, 1955, British Library Add MS 89182/1/15.

${ }^{27}$ Letter to Michael Goldstein from the Prince of Wales Theatre, Cardiff, 30 March 1956, British Library Add MS 89083/1/1/3/4.

${ }^{28}$ Letter to Henry Woolf from the Palace Theatre, Leicester, April 1957, British Library Add MS 89094/4/5.
} 
and enjoyment of the craft and $\mathrm{d}_{2}$ when relieved of the pressure of satisfying theatre audiences, he was later able to embrace these aspects in his screen performances.

\section{Multi-camera 1: A Night Out}

A Night Out was first broadcast on television on 24 April $1960 .^{29}$ It should be remembered that, at this point, Pinter was still less than acclaimed_-The Birthday Party had received largely negative reviews following its London opening in May 1958. A radio version of $A$ Night Out had already been broadcast by the Third Programme on 1 March 1960, with Barry Foster in the lead; the following month, Tom Bell starred in the ITV Armchair Theatre television version, directed by Philip Saville. The play focuses upon Albert Stokes, a young man regarded by colleagues as a 'mummy's boy', who seeks solace with a sex worker after a humiliating works party contretemps. In both versions Pinter played Albert's friend and colleague Seeley while his wife Vivien Merchant co-starred as 'The Girl', the would-be genteel lady of the night. Biographer Michael Billington claims this was primarily because they needed the money, a situation that would shortly change with the success of The

\section{Caretaker. ${ }^{30}$}

Seeley appears in two scenes. In the first, he and colleague Kedge (Philip Locke) dissect Albert's lacklustre performance in a recent company football match_-when he was bested by opposing team player Mickey Connor_while they wait at an outdoor snack bar for Albert to arrive. The second is at the party, where Albert is bullied by team captain Gidney (Stanley Meadows). For reasons of brevity, only the snack bar sequence will be examined here.

\footnotetext{
${ }^{29}$ A Night Out is available on Disc 1 of the Armchair Theatre: Volume One DVD (Network, 2012).

${ }^{30}$ Billington, Harold Pinter, 31
} 
After procuring their cups of tea, Seeley and Kedge sit and discuss the match, Seeley emphatically stating and re-stating that Albert would have fared better against Connor if he had only played 'his normal game' and waited for the faster player to come to him, rather than attempting to pursue him. Much of the humour derives from the fact that, although the less engaged Kedge seems ostensibly to be agreeing with Seeley, his statements contradict much of what he is saying, which merely spurs Seeley on to further exhortations. When Kedge states that Connor is a good player, Seeley replies: 'Well, no-one's denying he's good ... but he's not all that good, is he?' When Kedge then admiringly states that Connor is fast, Seeley reluctantly concedes: 'He's fast_... but he's not all that fast, is he?'

Pinter delivers a high-energy performance, making use of various gesticulations $\underline{\text { as }}$ $\underline{\text { Seeley discusses the game, though this could be a deliberate move to contrast his character }}$ with Philip Locke's more laconic Kedge. While the latter remains seated and static, Seeley stands and roams, first 'downstage' to the left of the set, then 'upstage' to the rear, lighting a cigarette as he ponders how the vindictive Gidney will respond to Albert's poor showing. Pinter's acting includes several traces of studio realism, which is characterised primarily by its 'scaled down' version of stage-derived codes. However, he is careful to keep his movements well within the frame, and his performance is not over-projected for the time. In addition, both Pinter and Locke incorporate naturalistic touches such as sipping from their mugs when it is the other's turn to speak, Locke's lackadaisical masticating, and Pinter's practised selection and lighting of a cigarette. Pinter also adds stammers and repetitions to Seeley's lines that help create what William Gillette termed 'the illusion of the first time' 'He's, he's, he's_... he's not all that good, is he?'; 'He's fast, but he's not... he's not all that fast, is he?' In this respect, it is interesting to compare the Armchair Theatre version of this scene with the earlier radio broadcast, in which John Rye played Kedge. While Pinter's use

\footnotetext{
${ }^{31}$ William Gillette, The Illusion of the First Time in Acting (New York, 2015), 21.
} 
of rhythm, intonation and word stress are similar, the radio play features less stammering and far fewer pauses for comic effect, Rye's rather flat reading of Kedge's lines giving Pinter less to play against than Locke's more considered, comedic performance. Interviewed in 1993, Pinter asserted that, for an actor, 'the rhythm and the music will tell you what you mean. You can work yourself into the ground, and you won't ever get anywhere unless you get the precise emphasis, and then the sense of the sentence will come clear'. ${ }^{32}$

While Pinter and Locke could be seen as slightly projected by modern standards, they also reflect the encroaching influence of 'kitchen sink' realism already evident in theatre and film, and are significantly scaled down from the 'outside in' acting of the theatre auditorium. ${ }^{33}$ The difference between the two is that by this point Locke had acquired nearly a decade's worth of experience of acting for television, whereas Pinter had primarily worked in rep and radio. His performance in A Night Out demonstrates that he is already well suited to television, despite a relative lack of technical experience. Louis Marks later observed that, when Pinter helmed a 1980 television adaptation of Simon Gray's Rear Column, in rehearsals he was initially unfamiliar with how the multi-camera set-up worked from a directorial standpoint, though he swiftly 'got completely on top of the technicalities' ${ }^{34}$ This makes his performance in A Night Out, which is both naturalistic (for the medium and the time) and technically proficient all the more remarkable, and it is perhaps to be regretted that the imminent success of The Caretaker meant he would no longer need to undertake regular acting work. However, it would be a mistake to take this single performance as entirely representative of his television performance style.

\footnotetext{
${ }^{32}$ Gussow, Conversations with Pinter, 108.

${ }^{33}$ See Judith Weston, Directing Actors: Creating Memorable Performances for Film and Television (Studio City, CA, 1996), 14, for the typical association of this 'projected' style with British actors.

${ }^{34}$ Louis Marks, 'Producing Pinter', in Pinter at Sixty, ed. Katherine H. Burkman and John L. Kundert-Gibbs (Bloomington, IN, 1993), 20.
} 


\section{Multi-camera 2: The Birthday Party}

By the time it was recorded for BBC's Theatre Night in March 1986, the once-reviled play The Birthday Party had achieved classic status. ${ }^{35}$ Writing to complain about the delay in broadcast until the following year, Pinter described this production as 'possibly the best account of the play ever given'. ${ }^{36}$ The cast includes Kenneth Cranham as the haunted lodger and former pianist Stanley, Joan Plowright as landlady Meg, Robert Lang as Meg's partner Petey, Julie Walters as neighbour Lulu, and Colin Blakely (in one of his last performances) as McCann, forming a sinister double act with Pinter's Nat Goldberg as the pair descend upon Meg's home and throw Stanley, hitherto the sole tenant, into a panic.

By the late $1980 \mathrm{~s}_{2}$ actors were used to the demands of multi-camera studio, and the process of 'scaling down' was more firmly established than in the $1960 \mathrm{~s} .{ }^{37}$ However, for Goldberg's opening conversation with Meg Pinter employs more overtly stage-derived codes of performance than in A Night Out_ perhaps unsurprisingly, given that The Birthday Party was designed for the theatre. This is reflected in the extremely forward-facing set design employed for the production. Director Kenneth Ives, who had already helmed The Dumb Waiter and One for the Road for the BBC's 1985 Summer Season, ${ }^{38}$ makes little attempt to 'open up' the narrative from the sitting room set in which the play takes place, other than including an opening shot of the hallway for Petey's entrance.

\section{The scene in which Goldberg questions Meg about the absent Stanley provides a} useful opportunity to examine Pinter's range as an actor, his air of jovial banter not quite masking the menace within. As Meg confuses a tale previously related by Stanley to produce a garbled account of his former life as a pianist. Goldberg responds to each statement with an innocuous 'Oh, yes?' before firing further questions at her. Only after Meg lets slip her belief

\footnotetext{
35 The Birthday Party is available on Disc 4 of the Pinter at the BBC_DVD (BFI, 2019).

${ }^{36}$ Letter to Controller of BBC2 Graeme MacDonald, 16 July 1986, British Library Add MS 88880/6/8/2.

${ }^{37}$ Hewett, The Changing Spaces of Television Acting, 117-164.

${ }^{38}$ Broadcast on BBC2 on 23 and 25 of July, respectively.
} 
(previously refuted by Stanley) that today is Stanley's birthday does Goldberg take the initiative, suggesting that he and McCann plan a surprise party for the elusive guest $=$ an idea Meg takes up with enthusiasm.

$\underline{\text { In this scene Pinter's use of voice is more projected, and hand gestures are more }}$ liberally employed, than in A Night Out; Pinter even mimes tinkling the ivories when enquiring whether Stanley can 'play a nice piano'. When Goldberg asks Meg, 'Weren't you going to have one [a party]?' Pinter extends his hand to emphasise the question, and gesticulates again twice on the line 'Well, of course you must have one. We'll have a party, eh, what do you say?' In light of his more scaled down performance as Seeley, these are clearly deliberate choices on Pinter's part; he has opted to perform Goldberg as a performer. Throughout the scene Pinter also makes a point of baring his teeth when Goldberg questions Meg about Stanley, his smile too quickly turning into a semi-snarl in order to signify that Goldberg's bonhomie is only part of an act, the seemingly innocuous questions in reality a prelude to his and McCann's later interrogation of Stanley.

Pinter's liberal use of hand gestures continues during the party scene, in which Goldberg makes a florid response to Meg's toast to the silent Stanley. Pinter then puts his hands to a very different use when Goldberg begins his flirtation with Lulu, rhythmically stroking her legs as the two characters suggestively discuss the playing of children's games. At this moment Pinter bares his teeth in an almost feral snarl to signify that Goldberg's avuncular mask is slipping.

In the final act, Pinter changes register to signify Goldberg's disquiet the morning after the party. It is notable that when Petey questions Goldberg as to the nature of Stanley's 'breakdown', Pinter avoids making eye contact with Robert Lang. Instead, he stares off into the middle distance, demonstrating that the hitherto bluff and confident Goldberg is growing increasingly unsettled. Similarly, the hand gesture Pinter makes when Petey asks whether 
Stanley might recover is vague and nervous rather than open or assertive: 'It's conceivable. Conceivable.'

Pinter takes this new aspect of Goldberg a step further in his subsequent conversation with McCann, again avoiding direct eye contact, and raising his hand to his brow to indicate Goldberg's agitation at the state of distraction he is experiencing. When McCann recommences his habit of methodically tearing strips from the pages of Petey's newspaper (performed by Blakely with comical concentration), Pinter continues to hold his head in his hand until exploding at his colleague, commanding him to desist. What then follows is a scene of near-disintegration for Goldberg, as he loses the sense of certainty that has thus far characterised Pinter's performance. As Goldberg attempts unsuccessfully to state his worldview, in an effort to pull himself together, Pinter again employs a stammer, as he did with the excitable Seeley, but this time it signifies Goldberg's lack of inner certainty, rather than excitement: 'Fo-fo-fo-Follow the line!'

By the end of the play, these signs of self-doubt have disappeared from Pinter's performance as the inarticulate and now myopic Stanley is finally subdued by Goldberg and McCann and strong-armed away to his new 'prospect'. However, these variations in style again indicate Pinter's sophistication as an actor, even when going to extremes to illustrate different aspects of one character. Another notable element is the extent to which Pinter's vocal delivery highlights Goldberg's Jewishness. Pinter himself, though born into the Judaic faith, did not attend a synagogue for anything other than family weddings and funerals following his own bar mitzvah, but has clearly coded Goldberg as Jewish in both his writing (he later ends his toast to Stanley with 'Mazel Tov!') and performance, particularly his throwaway delivery of the line 'Well, if we hadn't come today, we'd have come tomorrow'. Billington has cited Goldberg as an example of 'the complexity of Pinter's attitude towards 
the Jewish inheritance and shows how a dramatist may like and detest a character at the same time' and this aspect is clearly signalled in Pinter's performance. $\frac{39}{3}$

This was not the first time Pinter had essayed Goldberg. In July 1957, when he was still putting the finishing touches to the play, Pinter sent Mick Goldstein a letter claiming that he has used Goldberg as an audition piece for a theatre manager in Manchester: 'He nearly bust a gut laughing. He said_Who wrote that? I don't know it.—I did, says I. So he wants to see the play'. ${ }^{40}$ Interviewed by Mel Gussow in 1971 he stated that he had also played Goldberg on stage (though it has not been possible to substantiate this with archival sources), at which point he had been too young for the role. ${ }^{41}$ However, this 1986 performance shows him more than settled in the part. Interestingly, in the same interview Pinter stated that at the time of writing his plays he did not give any thought to which of the characters he would like to perform, but went on to reminisce about how, during his time in rep, his favourite role had been that of 'an MI5 man, immaculately dressed, with a moustache' — not a far cry from his 1986 rendering of Goldberg. ${ }^{42}$ Michael Billington has also stated that Pinter 'has always been particularly good at playing those of his characters ... who have a sharp, slightly spivvy, intimidatory quality'. ${ }^{43}$ The BBC performance was extremely well received within the upper echelons of the Corporation when eventually broadcast in 1987, with the Chairman of the Board of Governors Marmaduke Hussey writing to Pinter to praise his 'superb performance'. ${ }^{44}$

Aside of the fact that one of these two case studies was made in black-and-white and the other in colour, a viewer shown the two multi-camera performances out of context might

\footnotetext{
39 Billington, Harold Pinter, 82.

${ }^{40}$ Undated letter to Michael Goldstein from the Playhouse Theatre, Oxford, April 1957, British Library Add MS 89083/1/1/3/15.

${ }^{41}$ Gussow, Conversations with Pinter, 23.

42 Ibid.

${ }^{43}$ Billington, Harold Pinter, 129.

${ }^{44}$ Letter from Marmaduke Hussey, 22 June 1987, British Library Add MS 88880/6/8/7.
} 
be forgiven for assuming that Pinter's 1986 rendering of Goldberg is in fact the earlier example from a less televisually experienced rep actor, over-flexing their dramatic muscles, as compared with the more scaled down and medium_specific performance of Seeley. This, of course, would be a mistake. Recalling this production of The Birthday Party in 1988, Pinter himself remarked, 'Listen, I feel quite energetic', and this energy shines through in his grotesque-yet multi-dimensional-reading of a grotesque yet multi-dimensional character. ${ }^{45}$ These examples of Pinter's television work from 1960 and 1986 in fact demonstrate his flexibility as an actor via the conscious performance choices made. The same energy is present in each performance, but it is channelled to different ends, and in both it is notable how thoroughly at ease Pinter is in front of the cameras. As a stage actor, Pinter always claimed that he viewed the theatre audience as the 'enemy' = to be won over, or perhaps triumphed over. ${ }^{46}$ Here in a television studio, with no audience present other than the director and technical crew, he is freed of any such combative relationship.

It could be argued that, as author of these texts, Pinter had a particular insight as to how they should best be played. However, comments from those who worked with him suggest otherwise. After co-starring alongside Pinter in the 1993 stage revival of Home, Paul Eddington recalled that 'from the start he had ceased to be the author and became, as he said himself, just one of the actors ... it was not much use appealing to him for the meaning of an enigmatic phrase or arcane reference' ${ }^{47}$ This story chimes with another told by Alan Ayckbourn, and repeated by Pinter himself, when Pinter directed the future playwright in The Birthday Party in Scarborough in 1959: 'Alan said he had no idea what was going on in this play, and he said to me, "I wonder if I could ask you a few questions about my character. where do I come from? Can you tell me something about my background? ... And this

\footnotetext{
${ }^{45}$ Gussow, Conversations with Pinter, 77.

46 Ibid., 42.

${ }^{47}$ Paul Eddington, So Far, So Good (London, 1995), 226.
} 
fellow, Harold Pinter, put his glasses up his nose and said "Mind your own business!", ,48 Pinter's approach to character was, however, variable. He refused point blank to tell actor David Jones anything about McCann's background when the latter played him in a revival of The Birthday Party, stating 'I know everything about McCann after he walks through that door_-I know nothing about him on the other side'. ${ }^{49}$ Similarly, when Carey Perloff asked Pinter to sit in on rehearsals of The Birthday Party for his 1989 Classic Stage Company production, he discovered that 'he hates having to explain what something means. He trusts the characters so completely that he feels their behaviour should be taken as given and explored, not analyzed' ${ }^{50}$ However, Roger Lloyd Pack later recalled Pinter being far more particular with regard to character background when directed by him in Party Time: 'He gave everybody a background saying "You're probably someone in the City", or, "You're someone high up in the Civil Service." He knew how he wanted everything to be, down to the line readings'. ${ }^{51}$ As seen above, this variation in approach is also reflected in Pinter's own acting work.

\section{Single Camera 1: Rogue Male}

The next pairing of case studies features single camera film productions, neither of which was scripted by Pinter. In the first, Rogue Male, he appears in just one scene as lawyer Saul Abrahams, friend and facilitator to protagonist Sir Robert Hunter (Peter O’Toole), who has recently returned to England from pre-war Nazi Germany. Hunter was captured and tortured by the Gestapo after tracking Adolph Hitler to his mountain retreat, and following his escape has now turned to Abrahams for help. After quizzing Hunter regarding his plans over gull's

\footnotetext{
${ }^{48}$ Gussow, Conversations with Pinter, 111-112.

${ }^{49}$ Billington, Harold Pinter, 107.

${ }^{50}$ Carey Perloff, 'Pinter in Rehearsal', in Katherine H. Burkman and John L. Kundert-Gibbs (eds), Pinter at Sixty (Bloomington; Indianapolis, 1993), 7.

${ }^{51}$ Billington, Harold Pinter, 333.
} 
eggs and Moet Chandon, Abrahams provides his friend with funds to help elude his former captors. ${ }^{52}$

Pinter's performance as Abrahams shows him to be as at home with single camera location work (the view from the window indicates that this is a genuine office interior) as with multi-camera studio. Whereas the latter usually requires an actor to maintain continuous performance throughout a scene, single camera comprises a series of repeated takes after the initial master shot is complete. This necessitates increased attention to the minutiae of performance in order to ensure that each take matches in the final edit. The challenge here is that an action which 'reads' in close-up will not be as effective in long shot (and vice versa), so an actor must also be aware of technical aspects such as shot size and lens type when performing. The scene between Abrahams and Hunter begins in long shot as Abrahams welcomes Hunter into his office, which is then replaced by a medium shot of the two men as Hunter sits on Abrahams' desk after spotting a possible mole outside. There then follows a series of medium close up shot/reverse shots of Pinter and O'Toole, now seated either side of Abrahams' desk, as they discuss first Hunter's recent adventures, and then Abrahams' sense of not belonging to the English 'Establishment' due to his Jewish faith. Hunter retorts that Abrahams is as English as he, only for his friend to point out that Hunter is half-Irish. The scene then closes with another long shot, both actors in the frame once more as Abrahams furnishes Hunter with a money belt containing two thousand pounds.

Hand gestures are clearly part of what James Naremore would term Pinter's acting idiolect or personal 'set of performing traits'. ${ }^{53}$ Just as gesticulation accompanied his performances as Seeley and Goldberg to varying degrees, here he again employs an extended hand as Abrahams offers to de-shell the gull's eggs for Hunter, who hides his maimed digits

\footnotetext{
${ }^{52}$ The film is available as Rogue Male, DVD and Blu-ray (BFI, 2019).

53 James Naremore, Acting in the Cinema (Berkeley, Los Angeles, London, 1988), 4.
} 
beneath black gloves. However, this action is significantly scaled down from the previous multi-camera case studies in order to accommodate both the closer framing of the camera and the lower energy level of the scene. In addition, more subtle signifiers are employed to indicate subtext, such as Abrahams' slightly dismissive sniff before the line 'It may be peace in your time, but I don't think it's likely to remain peace in mine'=again referencing the social division that exists between him and the gentile Hunter. Interestingly, in Rogue Male Pinter is doing many of the same things as in his multi-camera television work, but performing them in a different way = particularly his portrayal of a character whose Jewishness is an important element of the script. Gone are the heightened gestures and broad accent of Nat Goldberg; Abrahams' faith here is primarily signified by his name and dialogue. In his way, Abrahams is as much a performer as Goldberg, playing the part of a cultured English gentleman lawyer__one he feels fools no-one__and this requires a lower key performance on Pinter's part.

\section{Single Camera 2: Catastrophe}

The final acting case study is David Mamet's production of Catastrophe, which was recorded as part of the Beckett on Film project and became one of the last performances Pinter gave before the discovery of the throat cancer that ultimately claimed his life. Written in 1982 and dedicated to imprisoned Czech playwright Vaclav Havel, Beckett's one-act play is a nonnaturalistic piece in which a Director and his Assistant arrange and rehearse a 'performance' featuring just one performer: the mute and compliant Protagonist. This character is written as a man standing on a platform in a long black dressing gown and wide-brimmed black hat, of which he is gradually divested by the Director in favour of 'whitening' his increasingly exposed flesh. Other instructions include the 'downing' of the Protagonist's head, meaning that his eyes should be downcast throughout the 'performance'. At no point is the Protagonist 
spoken to (though the Assistant does at least indicate concern that he is shivering), but in the closing action of the play he lifts his head to look directly at the audience, quietly defying the Director's dictates. ${ }^{54}$

Pinter had an affinity for Beckett, who was an early influence on his writing. The pair later became friends, meeting for the first time in Paris in 1961, and subsequently sending each other drafts of their work. In light of this it might be expected that, for the 2000 film adaptation, Pinter would produce a non-naturalistic reading as the hectoring Director, but__in line with the more realist tone and mise-en-scène adopted by Mamet, the action taking place in an authentic-looking theatre auditorium location $\_$he provides a Stanislavskian sense of naturalism, despite the bizarreness of the scenario and Beckett's stunted dialogue ('Why hand in pocket?').

Pinter primarily uses his voice to convey his character's arrogance and irritability, alternately barking commands at his note-taking Assistant (Rebecca Pidgeon) ('Light!) or disparaging her suggestions ('For God's sake!'), and seeing the Protagonist (Sir John Gielgud, in his last screen performance) as merely a vessel for his own vision. When the Assistant observes for the second time that their performer is shivering, Pinter invests the Director's line, 'Bless his heart', with a fake sympathy that drips with sarcasm. Movement is limited: the Director and Assistant first walk to the left of the screen, then sit to assess the impact of the mise-en-scène, and finally stand again. Pinter signifies the power relationship by always remaining at a distance from the Protagonist (the two never share the frame), obliging the Assistant to carry out the various physical adjustments the Director requires as he shouts them out. It is notable here that, untypically, Pinter makes little or no use of gesticulation, other than briefly raising his right hand to his mouth as the Director ponders

\footnotetext{
${ }^{54}$ Catastrophe was made available on Disc 1 of the Beckett on Film DVD (Tyrone Productions, 2005), now deleted. The film can be accessed at https://www.dailymotion.com/video/x2v84c (accessed_30 May 2019).
} 
that fact that something is still 'wrong' with the positioning of the Protagonist. When the Assistant suggests pointing the Protagonist's finger, a rare note of approval enters Pinter's voice, extending his own little finger as though in sympathy before the Director continues to command from a distance.

For much of the second half of the film Pinter is barely visible, the Director seating himself at the back of the hall as he calls for a blackout from the unseen stagehand, Luke. There is then a brief 'rehearsal', with the lights going up on Gielgud, and Pinter again allows some warmth to enter his voice as the Director crows over his creation: 'Lovely'. However, it is not long before he again becomes scornful, the Director disdaining the Assistant's suggestion that the Protagonist's head be raised to reveal his face; 'just an instant'. Pinter again manages to turn Beckett's clipped, derisive soundbites into a naturalistic-sounding tirade: 'What next? Where do you think we are? In Patagonia? Raise his head? For God's sake!'

As in the original play, at no point do the characters acknowledge the Protagonist's humanity, but in contrast to Beckett's original text, which implies at least a modicum of fellow feeling in the Assistant, Pidgeon's character is instead entirely subservient to and in accord with the Director; the moment in which she inadvertently sits in the Director's chair and then stands up and wipes it down, as though fearing contamination, is omitted. Another adjustment from Beckett's text is that the 'distant storm of applause' that dies away as the Protagonist fixes the audience with his stare becomes the Assistant enthusiastically clapping the Director's vision, alone and unfaltering, as Gielgud merely raises his eyes, caught in the spotlight, apparently unobserved. Whether an allegory of political tyranny or an explication of the self-sacrifice endemic to the actor's art, ${ }^{55}$ this scene ought to feel far more disjunctive

\footnotetext{
55 David Michael, “'There's our Catastrophe”: Empathy, Sacrifice and the Staging of Suffering in Beckett's Theatre', New Theatre Quarterly 17 (2001), 357-372, at 371.
} 
than it actually does. The fact that it does not is due to the naturalistic performance styles employed by Pinter and, to a lesser extent, Pidgeon; as a character, the Director is no less credible than Saul Abrahams.

\section{_Art, Truth \& Politics'}

Our final case study is not strictly speaking a screen acting role, but can be considered among Pinter's most significant performances. Having been notified in October 2005 that he had been awarded the Nobel Prize in Literature, Pinter recorded his acceptance lecture, 'Art, Truth \& Politics', on 4 December. ${ }^{56}$ It was screened for the Swedish Academy in Stockholm three days later, and subsequently broadcast on More4. The theatricality of this event, which saw the ailing Pinter, temporarily released from hospital, positioned in his wheelchair, blanket draped over his knees, with a large photograph of his younger self positioned behind him to the right of the screen, has been acknowledged by several commentators. Michael Billington was struck by Pinter's reliance on his actor's instinct 'for knowing how to reinforce a line or heighten suspense' and was not alone in admiring his technique. ${ }^{57}$ When Billington visited Stockholm for the ceremony that Pinter was too ill to attend, he learned that Sweden's young actors were as impressed by the delivery of the speech as its content. ${ }^{58}$ While many of those who wrote to congratulate Pinter were actors, including Timothy West, Miriam Karlin, Kika Markham, Penelope Wilton, Colin Firth and Tim Pigott-Smith, only fellow Hackney gang survivor-turned-thespian Henry Woolf focused at length on its performative nature:

\footnotetext{
56 The speech is available on the Harold Pinter: Art, Truth \& Politics DVD (Illuminations, 2006).

${ }^{57}$ Billington, Harold Pinter, 425.

58 Ibid.
} 
Your acceptance speech is powerful when read and just about twice as powerful on the screen. Most Nobel prize acceptance speeches are delivered by Top Chaps who have no idea how to use the medium of film to best advantage ... But as an experienced actor well aware of ... the opportunities of focus you generated great power with great stillness and economy, not, however, without an actor's subtle touches of 'business' and vocal modulation. A great and honest performance that illuminated the stark content of what you had to say admirably. ${ }^{59}$

As with A Night Out and The Birthday Party, Pinter is here performing his own material, albeit in the form of a lecture. He begins by considering the ways in which language informs his own work, comparing The Homecoming and Old Times with more overtly political pieces such as Mountain Language and Ashes to Ashes. However, the bulk of the lecture is comprised of examples of use of language by politicians that are markedly less precise than Pinter's, and it is here that his performing skills are most demonstrably on show.

The segment in which Pinter can arguably first be seen to be 'acting' is when he plays out a dialogue to which he was witness as a delegate on behalf of Nicaragua at the US Embassy in London in the 1980s. Pinter becomes first the missionary Father John Lewis Medcalf, a priest who highlights the attack on his parishioners by a Contra force when attempting to persuade Ambassador Raymond G. H. Seitz to withdraw US support for the terrorists. The language used here, invoking images of rape and slaughter, is plaintive and sincere, and these are the words Pinter-as-Medcalf emphasises in his delivery. Pinter then transforms into Ambassador Seitz as, in flat tones, he provides the inadequate rebuttal that, in war, innocents always suffer, adopting the hard logic of political pragmatism. Pinter then reverts to 'himself' as he relates the anecdote that, at the meeting's conclusion, a US aide told

\footnotetext{
${ }^{59}$ Letter from Henry Woolf, 21 December 2015, British Library Add MS 88880/11/10/101.
} 
Pinter he enjoyed his plays. There follows the most Pinteresque of pauses before he delivers the line, 'I did not reply' = with heavy emphasis on the word 'not'. At other points in the lecture Pinter impersonates US presidents Ronald Reagan and George W. Bush, adopting a dogmatic, evangelistic tone for the 'God is good' speech that he ironically proposes to write for the latter.

However, Pinter is still 'performing' even when not 'acting' these characters. At the beginning of the lecture he seems enervated, static in his wheelchair, and his use of hand gestures__as already seen, part of his performer's idiolect__is limited to the emphasis of certain lines, as when Pinter asserts that, in The Birthday Party, he believes he allows a range of dramatic options to be presented before settling on the act of McCann and Goldberg's subjugation of Stanley. The same gesture is then employed when Pinter ponders the "vast tapestry of lies' presented to the public by western politicians in order to justify the 2003 invasion of Iraq, his voice growing in strength and resonance as he solemnly intones the litany of (false) claims made by Bush and Prime Minister Tony Blair, repeating the line ${ }_{2}$ "We were assured that this was true. It was not true'.

There are also points at which Pinter, seemingly casually, adjusts the position of his glasses. This apparently innocuous gesture in fact signals a new direction for his polemic, the first coming as he concludes the opening section on use of language in his plays to focus on 'political language'. This gesture is later repeated when he (again ironically) states that America is 'the greatest show on the road'. That this action is deliberate is indicated by two of Pinter's previous screen appearances as 'himself': his 1984 interview with Benedict Nightingale for the ICA's Writers in Conversation series, and his 1997 appearance on Face to Face (BBC, 1989-1998), interviewed by Sir Jeremy Isaacs. ${ }^{60}$ On each of these occasions

\footnotetext{
${ }^{60}$ Pinter's Writers in Conversation segment was made for video release only. His Face to Face episode was broadcast on BBC2 on 21 January 1997.
} 
Pinter wears his glasses, and it is notable that at no point in the 1984 interview does he feel the need to adjust them. In the 1997 interview, during which Pinter appears somewhat less assured, he does nudge his glasses twice: first when questioned about being evacuated to Cornwall as a child, and again when animatedly discussing use of language in relation to hypocrisy. These are brief, almost agitated actions, and not the calm, considered signifier of his 2005 performance.

Other examples of Woolf's 'actors' business' include the loaded pause introduced by Pinter after describing the death and destruction brought to Iraq by the conflict, before proposing that Bush and Blair be prosecuted as war criminals. He then leans forward and clasps his hands as he provides Blair's home address__Number 10 Downing Street, London_lest the Court be confused as to where to contact him. It is touches such as these that inspired the admiration of his peers, Pinter drawing upon his acting skills in order to reinforce his message as a writer.

\section{Conclusion}

In 1993, Mel Gussow asked Pinter where he thought a career as an actor_might have led him. Pinter responded: 'I think I had the capability of being a reasonably intelligent actor' ${ }^{61}$ His modesty scarcely does Pinter's work credit, as it is this intrinsic intelligence that sets his screen performances at odds with the historical development of television acting, which saw most former repertory actors only gradually learning to scale down their stage performance style for the small screen. In contrast, Pinter was able to select whatever scale and style of performance was appropriate, no matter what stage he had reached in his acting career. This article is too brief to provide a full analysis and truly representative picture of his performing career, but these five case studies indicate that Pinter possessed a broad range in terms of

${ }^{61}$ Gussow, Conversations with Pinter, 141-142. 
technique, and had the rare ability to adapt his style both to text and performing environs. Pinter's career coincided with the growth of television as a mass medium and with the gradual development of a televisual style of acting. However, his performances are not those of a stage actor slowly adapting to screen work, as was often the case with others of his generation. ${ }^{62}$ Rather, Pinter as performer possessed a versatility that meant he was able at any point in his career to draw upon a variety of approaches in order to find the 'truth' =always the actor's objective__of the character being portrayed, without neglecting the technological specifics of his performing environment. Pinter was in this sense an atypical screen actor, and his work in this area deserves at least a measure of the attention paid to his written output.

${ }^{62}$ See Hewett, The Changing Spaces of Television Acting, comparing the performances of Reginald Tate and Isabel Dean, 31-40. 